\title{
Offshore Wind Energy Resource in the Kingdom of Morocco: Assessment of the Seasonal Potential Variability Based on Satellite Data
}

\author{
Aïssa Benazzouz 1,2,3,*(D), Hassan Mabchour ${ }^{1,4}$, Khalid El Had ${ }^{1}$, Bendahhou Zourarah ${ }^{2}$ and Soumia Mordane $^{3}$ \\ 1 Nautical Science and Naval Engineering Department, Institut Supérieur d'Etudes Maritimes, Km 7, \\ Road El Jadida, Casablanca B.P. 20520, Morocco; hassan.mabchour@gmail.com (H.M.); \\ elhad_khalid@hotmail.com (K.E.H.) \\ 2 Associated Unit URAC 45, Marine Geosciences and Sol Sciences Laboratory, Department of Geology, \\ Faculty of Sciences, University Chouaib Doukkali, El Jadida B.P. 20, 2400, Morocco; zourarah@gmail.com \\ 3 Polymer Physics and Critical Phenomenon Laboratory, Department of Physics, \\ Faculté des Sciences Ben M'Sik, Casablanca B.P. 20350, Morocco; mordanesoumia@gmail.com \\ 4 Department of Mechanics, Laboratory Mechanical Control and Characterization of Materials and Structures, \\ ENSEM, Casablanca B.P. 8118, Morocco \\ * Correspondence: benazzouz.metlisem@gmail.com
}

Citation: Benazzouz, A.; Mabchour, H.; El Had, K.; Zourarah, B.; Mordane, S. Offshore Wind Energy Resource in the Kingdom of Morocco: Assessment of the Seasonal Potential Variability Based on Satellite Data. J. Mar. Sci. Eng. 2021, 9, 31.

https://doi.org/10.3390/jmse9010031

Received: 29 November 2020 Accepted: 25 December 2020 Published: 31 December 2020

Publisher's Note: MDPI stays neutral with regard to jurisdictional clai$\mathrm{ms}$ in published maps and institutional affiliations.

Copyright: (C) 2020 by the authors. Licensee MDPI, Basel, Switzerland. This article is an open access article distributed under the terms and conditions of the Creative Commons Attribution (CC BY) license (https:// creativecommons.org/licenses/by/ $4.0 /)$.

\begin{abstract}
This study provides a first estimate of the offshore wind power potential along the Moroccan Atlantic shelf based on remotely sensed data. An in-depth knowledge of wind potential characteristics allows assessment of the offshore wind energy project. Based on consistent daily satellite data retrieved from the Advanced Scatterometer (ASCAT) spanning the period from 2008 to 2017, the seasonal wind characteristics were statistically analyzed using the climatological Weibull distribution functions and an assessment of the Moroccan potential coastal wind energy resources was qualitatively analyzed across a range of sites likely to be suitable for possible exploitation. Also, an atlas of wind power density (WPD) at a height of $80 \mathrm{~m}$ was provided for the whole Moroccan coast. An examination of the bathymetrical conditions of the study area was carried out since bathymetry is among the primary factors that need to be examined with the wind potential during offshore wind project planning. The results were presented based on the average wind intensity and the prevailing direction, and also the wind power density was shown at monthly, seasonal and interannual time scale. The analysis indicated that the coastal wind regime of the southern area of Morocco has the greatest energy potential, with an average power density which can reach in some places a value around $450 \mathrm{~W} / \mathrm{m}^{2}$ at heights of $10 \mathrm{~m}$ and $80 \mathrm{~m}$ above sea level (a.s.l) (wind turbine hub height) more particularly in the south of the country.
\end{abstract}

Keywords: offshore wind; wind energy resources; remote sensing; ASCAT

\section{Introduction}

We are currently experiencing a new era of climate change caused potentially by the use of traditional energy power-generating methods such as fossil fuels, which have a high environmental cost, both locally and globally [1-3].

A global trend is currently observed in terms of demand and acceptability of efficient and renewable energy. These are already considered as a reliable alternative with regard to the negative impact.

Worldwide, several countries are already resolutely turned towards wind energy, which is the case of China, world leader with installed capacity of 237 GW, the USA by $227 \mathrm{GW}$, Germany 78.9 GW, India $42.8 \mathrm{GW}$ and Spain with $48.1 \mathrm{GW}$ installed capacity [4].

Offshore wind has emerged as one of the most dynamic technologies in the energy system. In 2018, a total of $4.3 \mathrm{GW}$ of new offshore wind capacity was completed. From 
3 GW of offshore wind in operation in 2010, installed capacity expanded to 23 GW in 2018. Annual deployment has increased by nearly 30\% per year [5].

So far, in Morocco, no project has been installed or planned in offshore waters and to date no study has been launched on this segment. We hope that this paper contributes to arousing interest in the offshore wind power potential.

The wind resource is generally much greater offshore than over land for Morocco, with estimated potential of $250 \mathrm{GW}$, equivalent of 10 times the national wind energy potential onshore, of which $6 \mathrm{GW}$ could be installed by 2030 [6], and offshore wind farms can be built with very low negative environmental impact as stipulated by Haddouche [7]. Indeed, offshore wind farms are mostly located far from the main electricity consumption areas potentially limiting the benefits of their network services. Nevertheless, many large Moroccan cities are located close to the shoreline and already benefit from wind farm projects carried out or planned inland (Figure 1), which is advantageous for energy storage and can be attractive for deploying offshore power farms and reducing transmission lines.

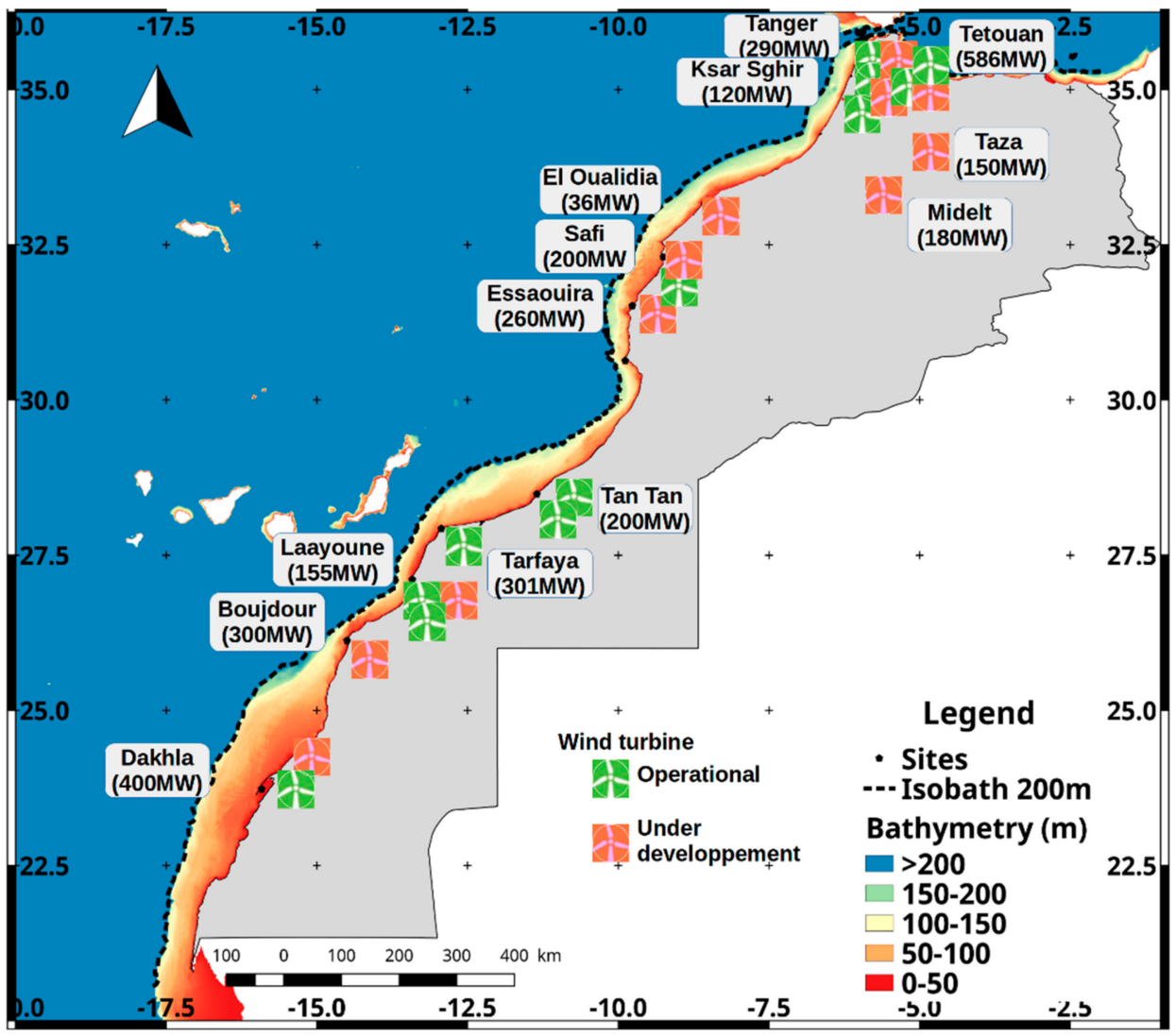

Figure 1. Study area showing the major sampled sites superimposed on the bathymetry of the Moroccan continental margin derived from the gridded chart of the European Marine Observation and Data Network (EMODNET) with the dashed isobath line of $200 \mathrm{~m}$ highlighting the width of the continental shelf (https:/ / www.emodnet-bathymetry.eu/data-products) [8]. Also, the energy map emphasizes the location of present and future wind farms projects by 2022.

Wind energy resources along the coastline are not known in much detail in Morocco despite the fact that several wind farms are being planned and are mostly erected on land $[9,10]$ with the exception of some works conducted to estimate the wind potential close to the shoreline such as Allouhi et al. [11] who tried to assess the wind energy potential at six coastal locations in the Kingdom of Morocco, namely Al Hoceima, Tetouane, Assila, Essouira, Laayoune and Dakhla based on hourly in situ measurements from 2011 to 2015 at heights of $50 \mathrm{~m}$ and $75 \mathrm{~m}$ inland but not at the body of the sea. Also, Elkhchine et al. [10] used the Weibull probability distribution function to evaluate the wind energy potential in 
two regions, Taza and Dakhla, over three years duration. The monthly mean wind speed variation, wind power density and energy output at different heights was also determined.

In this study, we used remote-sensing tools mainly derived from the Advanced Scatterometer (ASCAT) for retrieving time series and determining the spatial and temporal variability of wind speed frequency distribution along the Moroccan Atlantic Ocean along the continental shelf.

The scatterometer provides observations of the ocean surface wind variability over large areas at higher spatial and temporal resolutions from 2008 to 2017 since in situ measurements were not available. Furthermore, the satellite information is not yet demystified or fully exploited [12]. Such a long time series is valuable to assess the wind regimes and the corresponding energy quantities over coastal areas witch the most appropriate locations for wind project installation.

The analysis was carried out along the entire Atlantic shoreline with a focus on nine particular sites mostly located in the vicinity of the Cape. First, the data measured over a period of 10 years (2008-2017) was extracted and analyzed. The characteristics of wind such as mean wind speed, wind rose, extreme wind speed of each site were deduced. However, the deduced information was still exploratory for estimating the whole offshore wind resources around the Moroccan coastline until validated by in situ measurement. Despite low fourth degree resolution $\left(0.25^{\circ} \times 0.25^{\circ}\right)$, satellite products alone can be used to reliably assess offshore wind resource [13].

Based on ASCAT products, mathematical modelling of the wind field was carried out to determine the Weibull parameters giving the best fit with measured data to estimate the adequate wind distribution based on the probability density and cumulative distribution functions. Also, an atlas of the spatio-temporal wind power climatology describing the main monthly, seasonal and interannual variability pattern was provided. Results of wind resources assessment around along areas of Morocco were summarized in this paper.

This paper is structured as follows: first we present the study area including renewable resources in Morocco, particularly wind resources. The strategy was to develop the share of these resources in electricity production and the status of wind projects. In Section 3, materials and methodology to assess wind potential in selected sites. The results and discussion are in Section 4 and the conclusions in Section 5.

\section{Study Area}

Located in the extreme North-West of the African continent, along the Atlantic and Mediterranean sea between latitudes $20^{\circ} \mathrm{N}$ to $36^{\circ} \mathrm{N}$ and longitudes $1^{\circ} \mathrm{W}$ to $17^{\circ} \mathrm{W}$, Morocco is just $14 \mathrm{~km}$ from Europe across the strait of Gibraltar. Thanks to its large latitudinal extension, Morocco benefits from an important Atlantic shore $(2934 \mathrm{~km})$ and a very wide continental shelf (Figure 1) which is under the direct forcing of the subtropical anticyclones that surround the North Atlantic Ocean.

Morocco, a non-oil producing country, is over $96 \%$ dependent on the outside world for its domestic energy supplies [14], and the energy bill weighs heavily on its economic and financial balances. This dependence left Morocco rather exposed to the volatility of global energy prices.

The Kingdom of Morocco since 2008 has refined its energy strategy to better meet the challenges in terms of supply security, access to energy and environmental protection that aim to simultaneously decrease the dependence on foreign markets and increase the role of clean energy sources [15]. We can already see progress after recent years transitioning towards a decarbonisation of the electricity sector. This transition reduced the energy dependency ratio from $98 \%$ in 2008 to $93 \%$ in 2018 . The target is to increase the share of renewable energy to $42 \%$ ( $2 \mathrm{GW}$ solar and $2 \mathrm{GW}$ wind) of installed capacity by 2020 and to $52 \%$ by 2030 [15]. As cited by Kouskou et al. [16], at the end of 2017, the kingdom had already reached $34 \%$ of its capacity production [16]. 
Morocco is endowed with real advantages, notably its strategic position and the prospects for development of the renewable energy sector are very favorable thanks in particular to:

- Huge wind energy potential due to it $3500 \mathrm{~km}$ coast line with annual average wind speed exceeding $9 \mathrm{~m} \mathrm{~s}^{-1}$ at $40 \mathrm{~m}$ elevation. Therefore, the estimated total theoretical potential of wind power in Morocco is 25 GW [17].

- Solar potential illustrated by $3000 \mathrm{~h}$ of sunshine per year and $5 \mathrm{KWh} / \mathrm{m}^{2} /$ day of irradiation [11,18].

Despite these advantages, at the end of 2018 the installed capacity of renewable sources was $3685 \mathrm{MW}$ and equivalent to $33.8 \%$ of total production, including $1215 \mathrm{MW}$ of wind energy, representing $11.3 \%$ of the country's electricity production [19]. In 2019, the objectives registered a shift, and no new installed power was recorded (Table 1), which will impact the ambitious target of meeting $42 \%$ of its energy requirements using renewable resources by 2020 . The integrated wind program with $850 \mathrm{MW}$ has been delayed because of the recent reorganisation of energy sector. However, several projects are in progress, and by the end of 2022, around $2000 \mathrm{MW}$ will be installed [16,20].

Table 1. Status of Morocco wind projects by the end of 2020.

\begin{tabular}{|c|c|c|c|c|}
\hline City & Project & Capacity (MW) & Date of Commissioning & Statute \\
\hline \multirow{3}{*}{ TANGER } & HAOUMA & 50 & 2013 & Operational \\
\hline & TANGER I & 140 & 2010 & Operational \\
\hline & TANGER II & 100 & 2020 & In progress \\
\hline KSAR SGHIR & JBEL KHELLADI & 120 & 2017 & Operational \\
\hline \multirow{4}{*}{ TETOUAN } & ABDELKHALEK TORRÈS & 54 & 2000 & Operational \\
\hline & LAFARGE & 32 & 2011 & Operational \\
\hline & KOUDIA BAIDA & 200 & 2020 & In progress \\
\hline & TAQA NORD & 200 & 2020 & In progress \\
\hline TAZA & TAZA-PEI PHASE I & 150 & 2021 & In progress \\
\hline MIDELT & MIDELT-PEI & 180 & 2020 & In progress \\
\hline EL OUALIDIA & El OUALIDIA & 36 & 2020 & In progress \\
\hline SAFI & SAFI & 200 & 2021 & In progress \\
\hline ESSAOUIRA & JBEL LAHDID—PEI & 200 & 2021 & In progress \\
\hline \multirow{2}{*}{ TANTAN } & AKHEFNIR I & 100 & 2013 & Operational \\
\hline & AKHEFNIR II & 100 & 2017 & Operational \\
\hline \multirow{2}{*}{ TARFAYA } & TARFAYA & 301 & 2014 & Operational \\
\hline & AMOGDOUL & 60 & 2007 & Operational \\
\hline \multirow{3}{*}{ LAAYOUNE } & CIMAR & 5 & 2012 & Operational \\
\hline & FOUM EL OUED & 50 & 2013 & Operational \\
\hline & TISKRAD—PEI & 100 & 2022 & In progress \\
\hline BOUJDOUR & BOUJDOUR—PEI & 300 & 2021 & In progress \\
\hline \multirow{2}{*}{ DAKHLA } & AFTISSAT II & 200 & 2022 & In progress \\
\hline & AFTISSAT I & 201.6 & 2019 & Operational \\
\hline
\end{tabular}

\section{Materials and Methods}

\subsection{Remote-Sensing Data Collection}

The remotely sensed wind velocity components at $10 \mathrm{~m}$ above the sea surface are extracted from the Advanced Scatterometer Satellite (ASCAT) database available at http:/ / apdrc.soest.hawaii.edu/datadoc/ascat.php. The ASCAT data were processed by the National Oceanic and Atmospheric Administration (NOAA) utilizing measurements from ASCAT aboard the EUMETSAT (European Organisation for the Exploitation of Mete- 
orological Satellites)/METOP (polar orbiting meteorological satellites) satellite at C-band. The data is used over 10 years (2008-2017) with daily chronological period which estimates near-surface wind speed at 10 ma.s.l by measuring the ocean's surface roughness. The data are mapped into $0.25^{\circ} \times 0.25^{\circ}$ grid latitude/longitude along the Moroccan domain extended from $20-36^{\circ} \mathrm{N}$ of latitude and $30-5^{\circ} \mathrm{W}$ of longitude. The wind climatology is constructed in order to highlight of the offshore wind along the national coastline.

Although, in order to ensure the reliability of the ASCAT product for the estimation of the wind potential, an attempt was made to compare at daily timescale the in situ data initially recorded three-hourly along a full year (2018) at the Dakhla weather station with the satellite data.

\subsection{Methods}

Statistical analysis was carried out to determine the wind energy potential along the entire Moroccan area with special attention to some given sites (Table 2) and estimate the wind energy output. To describe the statistical distribution of wind speed, various probability functions exist throughout literature for wind regimes. According to [21], Weibull distribution has a very wide range of applicability, with an acceptable accuracy level. This function has the advantage of making it possible to quickly determine the average of annual production of a given wind turbine [22]. However, the main limitation of the Weibull probability density function (PDF) is that it does not exhibit exactly the probabilities of low wind speeds [23].

Table 2. Geographic information of the selected sites.

\begin{tabular}{ccc}
\hline \multirow{2}{*}{ Sites } & \multicolumn{2}{c}{ WGS84 Coordinates } \\
\cline { 2 - 3 } & Longitude (West) & Latitude (North) \\
\hline Cap Spartel & -5.99 & 35.80 \\
Safi & -9.30 & 32.24 \\
Essaouira & -9.77 & 31.51 \\
Cap Ghir & -9.65 & 30.43 \\
Tan Tan & -11.36 & 28.46 \\
Tarfaya & -12.93 & 27.94 \\
Laayoune & -13.46 & 27.12 \\
Boujdour & -14.50 & 26.12 \\
Dakhla & -16.02 & 23.66 \\
\hline
\end{tabular}

The detailed geographic information of the nine sites along the Moroccan coastline are shown in Table 2 and Figure 1.

\subsubsection{Weibull Distribution}

Weibull modelling is general, It's encompasses exponential distributions or Rayleigh that are only specific cases of this function [23]. The function of Weibull can be described by two or three parameters. A Weibull model with three settings is more general and more flexible but the parameters are much more complexes to be determined [24]. In order to comply with the standards of the wind industry, we use the two-parameters Weibull probability density function $(P D F)$, and the mathematical expression is as follows $[25,26]$ :

$$
\operatorname{PDF}(V)=\left(\frac{k}{c}\right)\left(\frac{V}{c}\right)^{k-1} \exp \left[-\left(\frac{V}{c}\right)^{k}\right], \text { for } 0 \leq V, \mathrm{k}>1 \text { and } \mathrm{c}>0
$$

where $k$ is the Weibull shape parameter which describes the dispersion of the data, (it indicates a more or less great dissymmetry of the distribution of the wind speeds), $c$ is the scale parameter which is related to the average speed by the function gamma (it characterizes, like the average, the intensity of the wind), and $P D F(V)$ is the probability of observing wind speed $V\left(\mathrm{~m} \mathrm{~s}^{-1}\right)$. 
The corresponding function to the PDF is the CDF which stands for Weibull cumulative density function (CDF) of observing wind speed $V$ obtained by integration the Equation (1) [27] given as:

$$
C D F(V)=1-\exp \left[-\left(\frac{V}{c}\right)^{k}\right]
$$

The fitted probability density function is characterized by a scale parameter $(c)$ and a shape parameter $(k)$, which may be used to determine the mean wind speed and the wind power density. This was performed for each pixel along the coastline of the study area.

Wind speed is the key indicator for assessing wind potential [21]. The expression of the averaged daily climatological wind speed $\left(V_{a v g}\right)$ is obtained as follows:

$$
V_{\text {avg }} \frac{\sum_{i}^{n} V_{i}}{n}
$$

and the associated standard of deviation is:

$$
\sigma v=\left[\frac{1}{(n-1)} \sum_{i=1}^{n}\left(V_{i}-v_{\text {avg }}\right)\right]^{1 / 2}
$$

For $1 \leq k \leq 10$ approximation of the following equation is used [28]:

$$
k=\left(\frac{\sigma v}{V_{a v g}}\right)^{-1.086}
$$

where $\sigma v$ is the standard deviation.

Scale factor ' $c$ ' can be found from the following empirical approximation:

$$
c=\left(0.568+\frac{0.433}{k}\right)^{\left(\frac{-1}{k}\right)} V_{a v g}
$$

\subsubsection{Evaluation of Wind Power Density (WPD)}

The evaluation of the wind power density (WPD) is of fundamental importance in assessing wind power project. In our study, WPD was calculated from the probability density and the wind speed at 10 ma.s.l for the nine sites.

Wind power density $\left(E\right.$ in $\left.\mathrm{W} / \mathrm{m}^{2}\right)$ is directly proportional to air density and can be defined from the instantaneous values of $\mathrm{V}$ as in [29]:

$$
E=0.5 \rho V^{3}
$$

At sea level and under standard conditions (temperature of $25{ }^{\circ} \mathrm{C}$ and pressure of 1 atmosphere), the air density $(\rho)$ is about $1.225 \mathrm{~kg} / \mathrm{m}^{3}$.

\subsubsection{Wind Speed Vertical Extrapolation}

The ASCAT wind speed is given at the height of $10 \mathrm{~m}$ a.s.l, while the wind speed increases with height. The energy extracted by the wind turbine is estimated using wind speed at the turbine hub height. However, there are theoretical expressions used for determining the wind speed profile. The extrapolation is expressed by the logarithmic wind profile [30] that correlates the wind speed at two different heights, for neutral conditions of atmospheric stability in which thermal effects have been neglected by the following equation:

$$
v=v_{0} \frac{\ln \left(\frac{h}{z_{0}}\right)}{\ln \left(\frac{10}{z_{0}}\right)}
$$


in which, $v$ is the speed that must be calculated at hub height $h, v_{0}$ is the wind speed measured at height $10 \mathrm{~m}$ above sea level, and $z_{0}$ is the surface roughness parameter length which is frequently assumed as a value of $0.0002 \mathrm{~m}[31,32]$.

The power law was used to extrapolate the Moroccan offshore mean wind speed derived from satellite data to the hub power height of $80 \mathrm{~m}$ a.s.l.

\section{Results and Discussion}

\subsection{Comparison of Scatterometer Winds and In Situ Measurement}

In order to ensure the reliability of the ASCAT product for the estimation of wind potential along the Moroccan shoreline, the Scatterometer winds from ASCAT were roughly compared with in situ data recorded over entire year 2018 at the Dakhla meteorological station by using the density plot.

Globally, the wind speeds from Scatterometer potentially matched the in situ wind measurements where the number of collocated Scatterometer and in situ wind measurements was higher (Figure 2). However, some discrepancies could be observed between both products about the regression line. We noticed that the ASCAT product tended to underestimate the wind potential mainly during summer months when the wind is strong. In fact, the goodness of fit strongly depended on the datasets which contained too few samples in our case (data is over a single year with a daily time step), which made it difficult to compare results from both wind products. Second, we compared a geographically localized in-situ data at land with ASCAT data of coarse spatial resolution $\left(0.25^{\circ}\right)$ in the body of the sea. Regardless of that, it is very hard to comment on the statistical uncertainties while the adequacy between both products is acceptable $(R=0.82)$ and followed a similar pattern distribution (Figure 3).

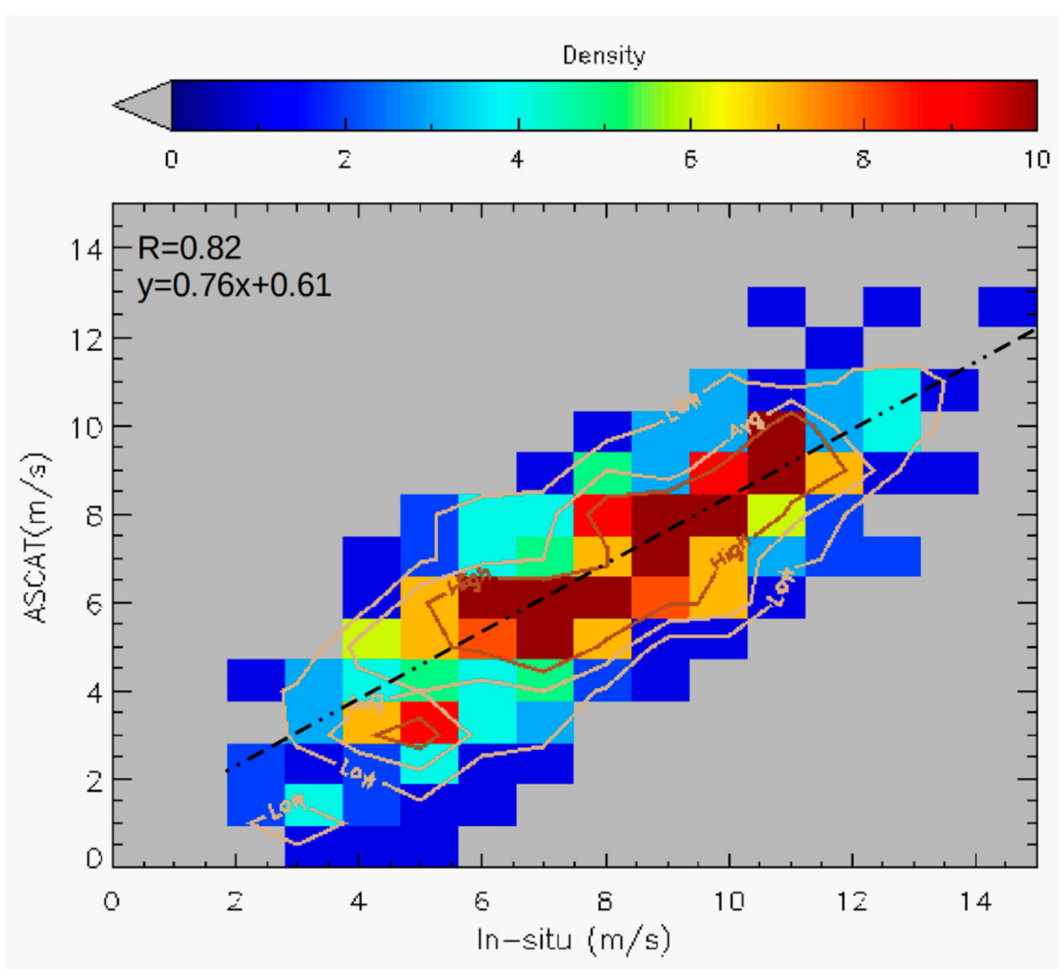

Figure 2. Density plot and regression line for Scatterometer winds with respect to in situ measurements winds for 2018 at the Dakhla site; the colour bar indicates the number of collocated Scatterometer winds. 


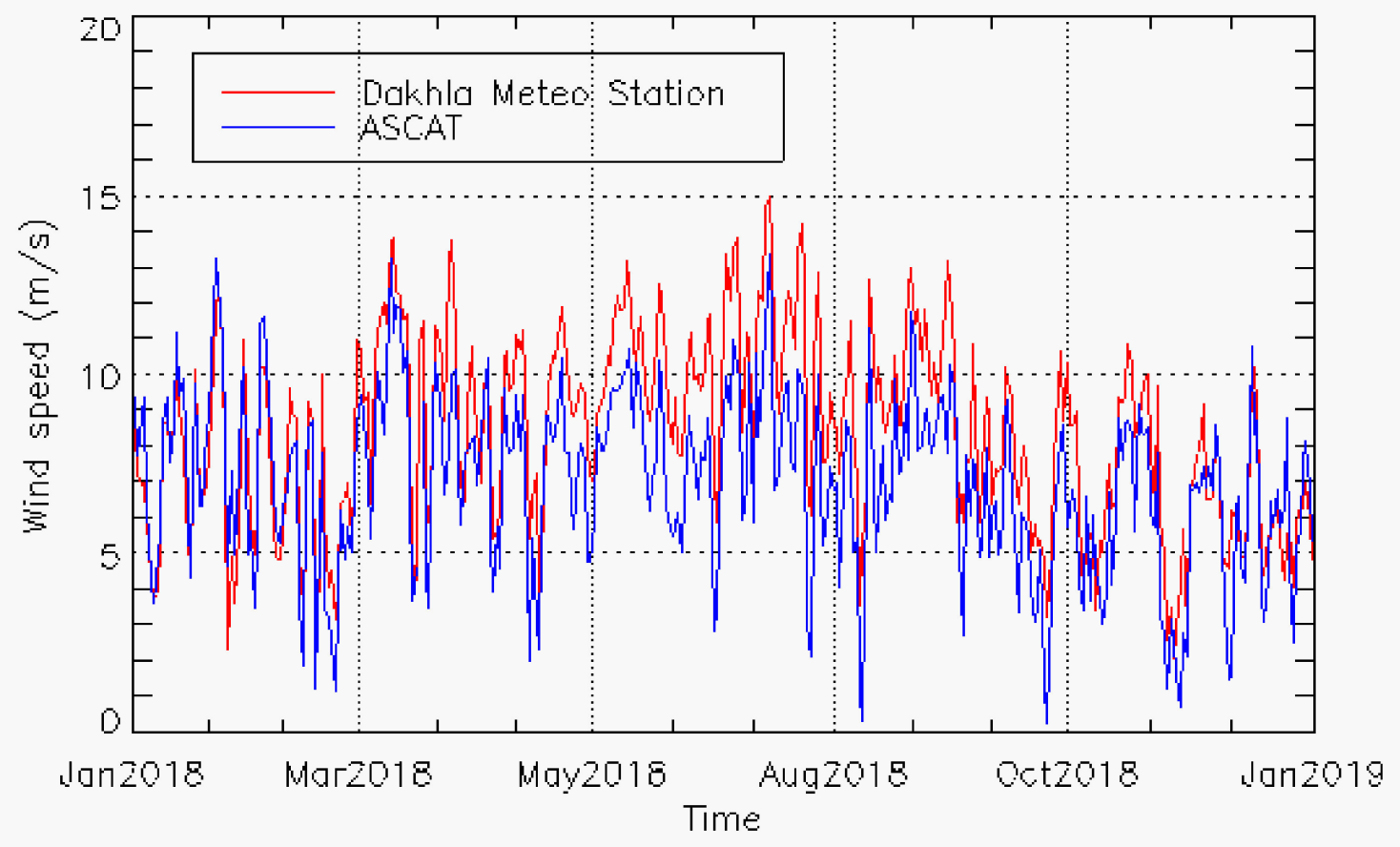

Figure 3. Temporal wind variability based on daily in-situ measurement and Advanced Scatterometer (ASCAT) product during the year of 2018 .

\subsection{Seasonal Variability}

In order to highlight the general pattern of the climatological seasonal wind speed changes at $10 \mathrm{~m}$ a.s.l and the behavior of daily-averaged variability along the coastal band, the spatio-temporal plot drawn as Hovmoller diagram was computed (Figure 4) [33].

The processing was carried out based on the average wind velocity intensity over the first three pixels furthest from the coastline where the wind retrieval within $25-75 \mathrm{~km}$ (1-3 pixel widths) from the coast line [33] is not land contaminated. Afterwards, the daily zonal (u) and meridional (v) components were separately extracted and used for computing the wind intensity and mapping the wind direction.

The spatio-temporal changes of the offshore wind speed (Figure 4) showed a general southward increase of the wind intensity thus causing a very marked seasonality between north and south along the coast. The resulting seasonal wind pattern showed a windy region with a slight seasonal maximum variability between North and South. Large variability is seen in spring and winter, whereas weak variation are recorded in summer and autumn seasons. As depicted, the northern part $\left(30-36^{\circ} \mathrm{N}\right)$ of the studied area $\left(20-36^{\circ} \mathrm{N}\right)$ shows a more irregular wind field with moderate mean wind speeds occurs mainly during the summer and autumn $\left(2-4 \mathrm{~m} \mathrm{~s}^{-1}\right)$ and low mean intensity during the winter and late spring $\left(3-2 \mathrm{~m} \mathrm{~s}^{-1}\right)$, while the central part $\left(26-33^{\circ} \mathrm{N}\right)$ shows a strongly seasonal wind intensity during summer $\left(\sim 9 \mathrm{~m} \mathrm{~s}^{-1}\right)$. However, the southern part $\left(20-26^{\circ} \mathrm{N}\right)$ has a quite regular, highly intense (more than $10 \mathrm{~m} \mathrm{~s}^{-1}$ ) and permanent wind which is blowing throughout the year.

It is clear that the summer months have a high wind speed compared with other months. 


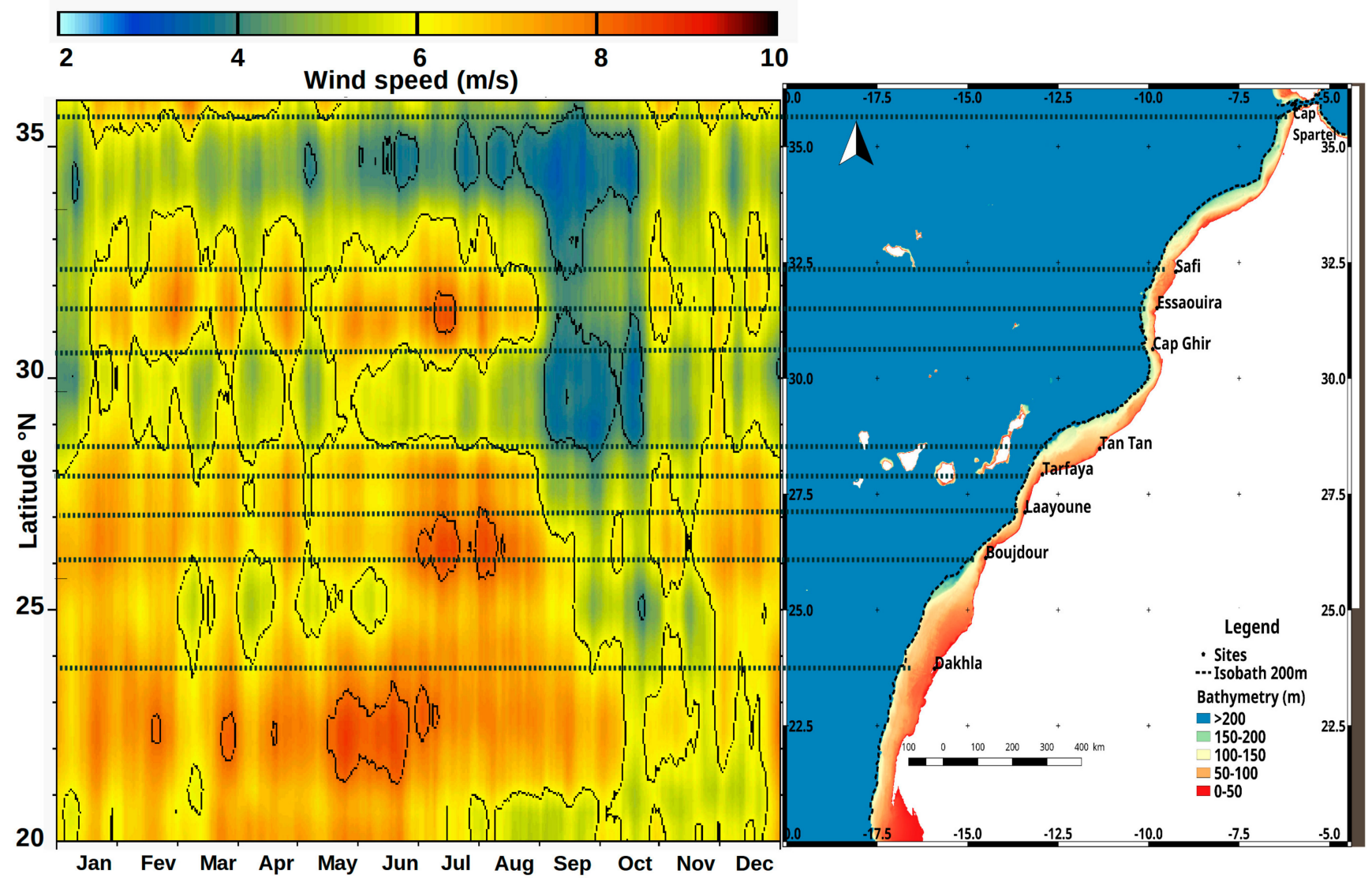

Figure 4. Hovmoller diagram of the climatological ASCAT wind intensity with a spatial resolution of 0.25 degrees and daily time step along the entire Moroccan area at $10 \mathrm{~m}$ height a.s.l; the dashed lines denote the sites sampled and considered for an assessment of the energy potential.

\subsection{Wind Roses}

The assessment of a region's wind energy consists of determining the distribution of wind speed and direction. The result is a wind rose which indicates the frequency of wind blowing in different directions and suitable locations for the installation of wind turbines.

Wind rose plots are shown in this study, and may contain an additional information from that obtained by the Hovmoller diagram. The climatological daily frequency distributions of wind speed and direction at $10 \mathrm{~m}$ a.s.l show the intensity of prevailing wind for the nine selected sites (Figure 5).

On a climatological time scale, wind roses reveals steadily variations in the annual wind behavior. The mainly prevailing wind directions of the Moroccan atmospheric circulation at sea surface over the selected sites are the North (N), North-north-east (NNE) and North-east (NE). Those three directions comprise about $80 \%$ of all climatological daily directions. On all the selected sites, it is rare that the wind blows from the south.

The most intense wind is recorded in sites located much further south especially in the Dakhla, Boujdour and Laayoune followed by the sites of Tarfaya, Tan Tan Cap Ghir and Essaouira.

The diagrams indicate also that the most frequent and highest wind direction originates from the North-East reaching a speed in the range of $9-12 \mathrm{~m} \mathrm{~s}^{-1}$. Southerly and Westerlies winds are mainly observed at Cap spartel and Safi, and are least frequent for the rest of the sites and give rise to low and moderate speeds. However, it can be estimated that the wind circulation is much more intense where days of calm or very low wind $\left(<3 \mathrm{~m} \mathrm{~s}^{-1}\right)$ [34-36] represent only a very small percentage which does not exceed $20 \%$ of the cases. In all directions, high speeds are very common. Fairly strong winds $\left(9-12 \mathrm{~m} \mathrm{~s}^{-1}\right)$ is the dominant pattern of North-east winds. 


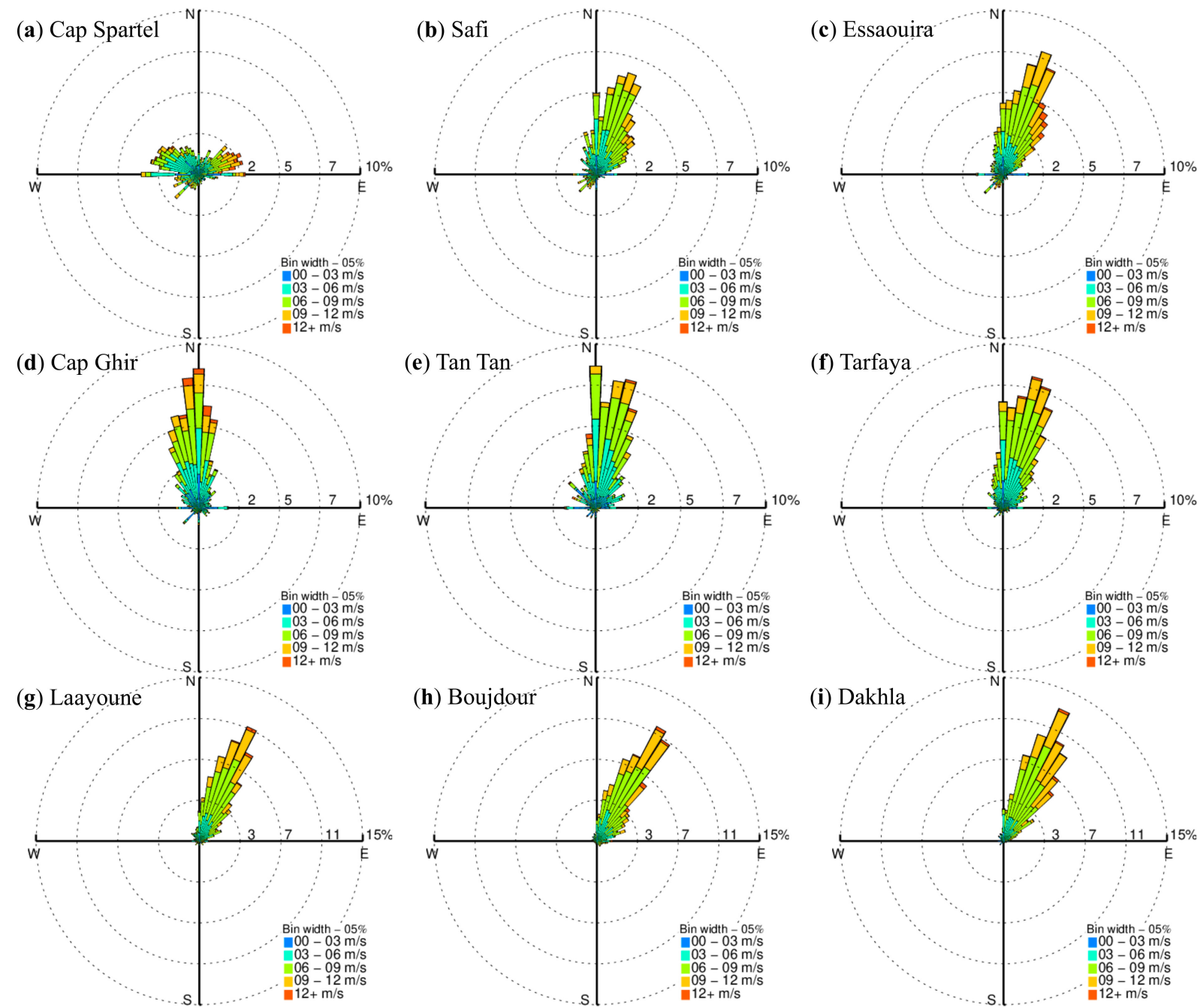

Figure 5. Wind roses diagrams giving measured wind speed frequency and its corresponding wind directions for the nine selected sites; different scales of [0-15\%] are used for (g) to (i).

Regarding direction, the analysis shows that there is a predominance of wind in the sector from North-Northeast (NNE) to East-Northeast (ENE). The higher wind is recorded in the North-East direction (NE). In addition, this interval is the largest contributor to total energy. Despite a frequency of significant speeds in the North-west (NW) to South-west (SW) sector, the speed mean wind remains low.

\subsection{Interannual Variability}

The space-time diagram of the offshore wind, as computed from daily ASCAT wind (Figure 6), shows the seasonal and interannual variations of the wind regime for the study period at $10 \mathrm{~m}$ a.s.l. It highlights the latitudinal variations in wind intensity oscillation and seasonality, as well as in terms of spatio-temporal extent.

The offshore wind speeds show a very marked oscillation from year-to-year over continental Morocco as whole. We have noted also that, usually, the wind pattern repeats itself year-on-year. The interannual variability exhibit evident regional differences. It's more pronounced in the northern area (North of Safi) with lower intensity and in the central part (from Tan Tan to Safi) with peaked intensity occurring mainly at the middle of each year. The smaller interannual variation occurring in southern Morocco $\left(21^{\circ} \mathrm{N}-26^{\circ} \mathrm{N}\right)$ with the greatest intensity where the wind is blowing permanently. 
The whole time period was characterized by a considerable year to year variability and oscillations between periods of strong $(2008,2010,2014,2015$ and 2016) and weaker wind intensity $(2009,2013,2017)$.

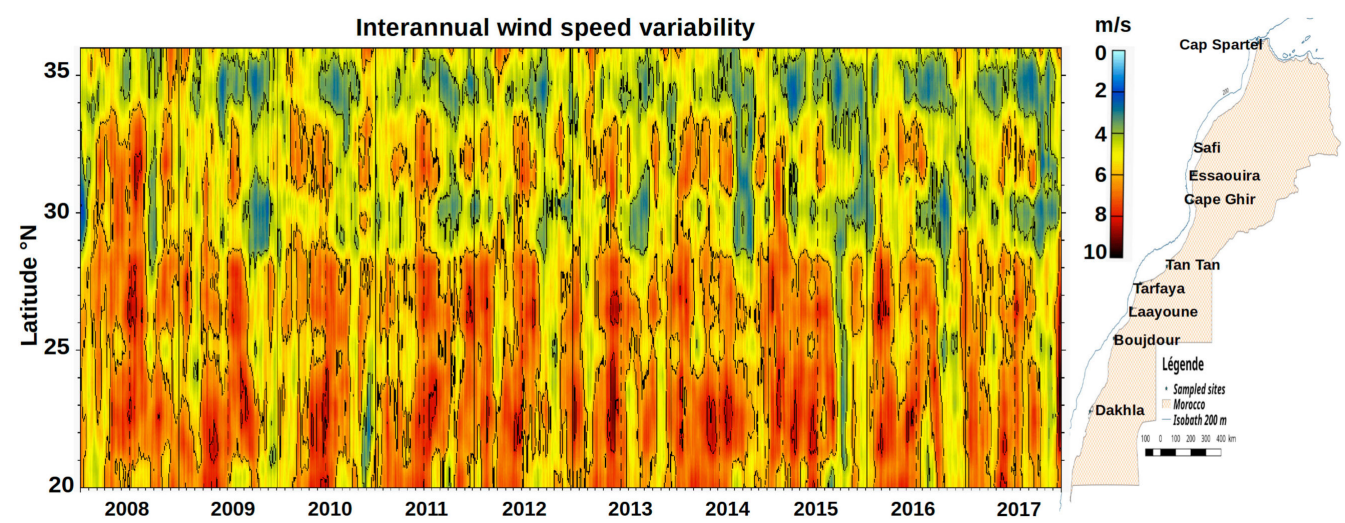

Figure 6. Space-time Hovmoller plot, illustrating the seasonal and interannual variability of the wind intensity from January 2008 to December 2017.

\subsection{Weibull Distribution}

Using the Weibull distribution presented in Section 3.2.1 for the variation of the standard deviation values, the shape (K) and scale (C) parameters for each grid point of the region along the coastal band were performed. This allowed the calculation of average speed, average power density and the cumulative distribution function (CDF) for the nine sites as shown in Figure 4.

The Hovmollers plots (Figures 6 and 7) and histograms (Figure 8) show, respectively, the monthly and seasonal variation of the Weibull parameters and the probability density function for various values of $\mathrm{k}$ and $\mathrm{c}$ at height $10 \mathrm{~m}$ a.s.l for the whole region. It can be depicted that when the value of $\mathrm{k}$ increase, the wind speed variation is less marked and the standard deviation is reduced (Figure 7) giving useful information for industry providing a stability index of the wind over the years.

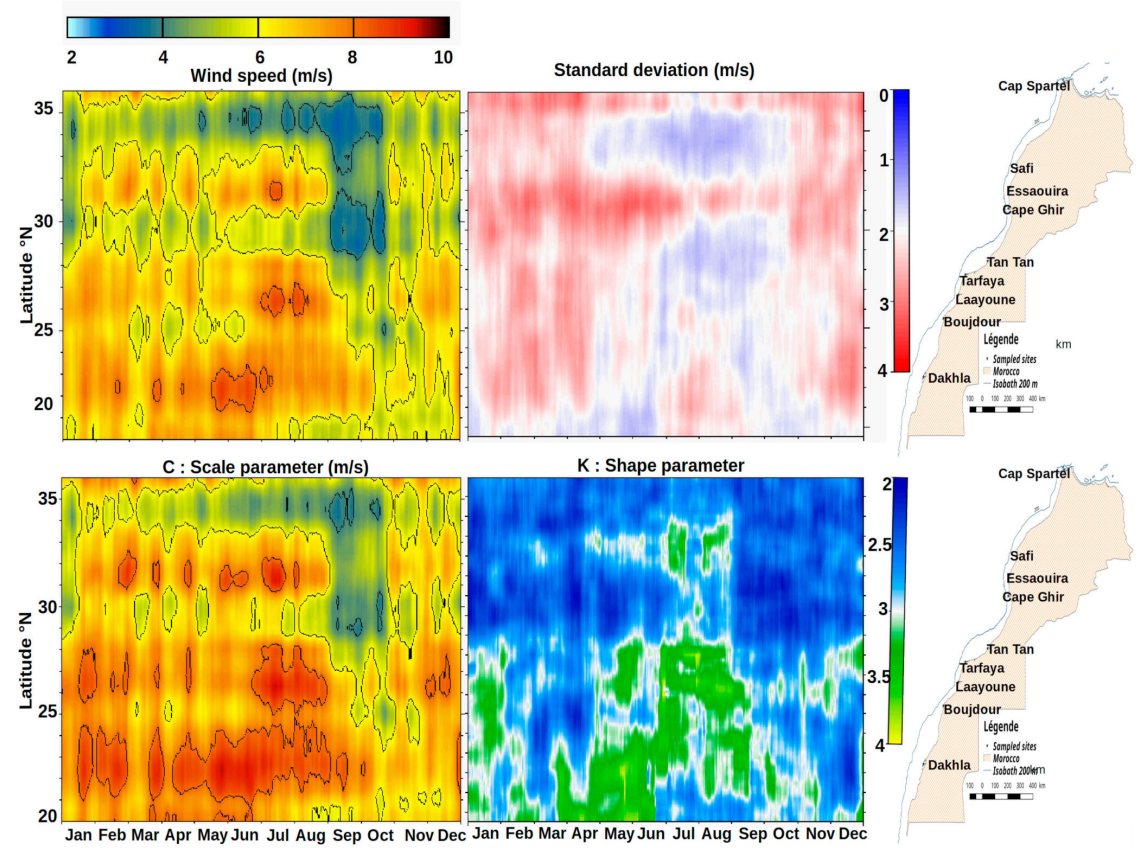

Figure 7. Weibull parameters, wind speed and the corresponding standard deviation. 


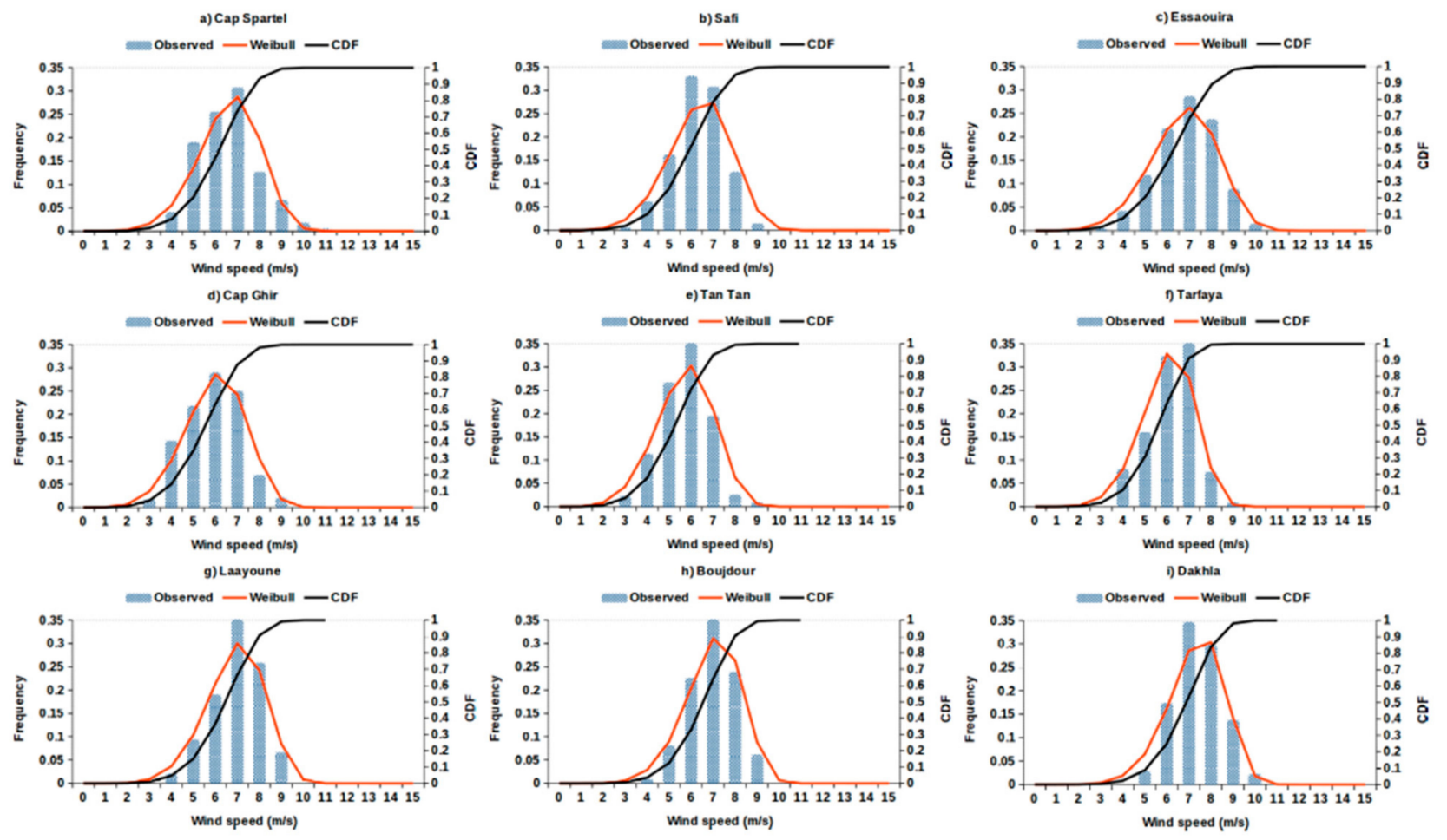

Figure 8. Climatological comparison of the observed and the predicted wind speed frequencies associated with the cumulative distribution function for the nine sites.

The relatively higher scale parameter for the months of March to August with a peak value of $8.97 \mathrm{~m} \mathrm{~s}^{-1}$ in July at the Dakhla site, and a slight decrease in September $\left(4.27 \mathrm{~m} \mathrm{~s}^{-1}\right)$ and October $\left(4.61 \mathrm{~m} \mathrm{~s}^{-1}\right)$ was observed. We can also notice that it is maximal in summer months $\left(\sim 7 \mathrm{~m} \mathrm{~s}^{-1}\right)$ while the shape factor ranges from 2 January to 5 September. In addition, the shape factor increases considerably in the middle of the year between May and October. Indeed, these maximum values are 4.3 and 3.7 when calculated, respectively, in spring and summer months. It explains that during the warm months, even if the wind is relatively high, it is uniform, constant and stable during this period.

In order to complete our analysis of the wind behavior, the mean wind frequency classification for the nine sites is expressed and displayed (Figure 8).

Frequency analysis of wind speed being expressed directly (as a percentage) or cumulatively highlights the frequency of occurrence, which allows us to know the probability that a speed value is not exceeded.

It can also be observed from Figure 8 that the forms of the PDFs are almost symmetric where the highest wind speed probabilities are in the range of $6-8 \mathrm{~m} \mathrm{~s}^{-1}$.

A predominance of the $6-8 \mathrm{~m} \mathrm{~s}^{-1}$ range is shown which represents $80 \%$ of the cases with a minimum for the range of $1-3 \mathrm{~m} / \mathrm{s}(5 \%)$. Almost more than half of the values are greater than or equal to 6-7 $\mathrm{m} \mathrm{s}^{-1}$ (high wind).

Moderate winds (less than $5 \mathrm{~m} \mathrm{~s}^{-1}$ ) represent $15 \%$ of the cases and fairly strong and strong winds (6-8) $80 \%$. Finally, strong and very strong winds (greater than or equal $10 \mathrm{~m} \mathrm{~s}^{-1}$ ) represent only $5 \%$ of cases. We noted that for the Cap Spartel, Safi and Essaouira sites, $85 \%$ of the data are accumulated in the range of $4 \mathrm{~m} \mathrm{~s}^{-1}$ to $8 \mathrm{~m} \mathrm{~s}^{-1}$ and the range of the velocity distribution is up to $9 \mathrm{~m} \mathrm{~s}^{-1}$. For the Tarfaya site, $85 \%$ of the velocity data is is higher than $6 \mathrm{~m} \mathrm{~s}^{-1}$ and only $10 \%$ is in the range of $1 \mathrm{~m} \mathrm{~s}^{-1}$ to $4 \mathrm{~m} \mathrm{~s}^{-1}$. As for the Tan Tan site, $85 \%$ of the data are recorded in the range of $5 \mathrm{~m} \mathrm{~s}^{-1}$ to $8 \mathrm{~m} \mathrm{~s}^{-1}$ and the speed range extends up to $10 \mathrm{~m} \mathrm{~s}^{-1}$.

The most windy sites are the Boujdour, Laayoune and Dakhla sites with $7 \mathrm{~m} \mathrm{~s}^{-1}$ annual average speed. They have also the most interesting available energy output and thus represent the most favorable sites for using wind energy for electricity production. 
Plots of Figure 8 show that the Weibull function do not always fit the real data specially during the wind decrease in summer, specifically at some locations. This probably explains the overestimation of the scale parameter of the Weibull function.

Consequently, the direct use of the instantaneous wind power density directly derived from the instantaneous wind speed could give a much better result.

\subsection{Mean Wind Power Densities}

The mapping of the monthly climatological WPD at $80 \mathrm{~m}$ a.s.l exhibits a marked monthly spatial variability along the Moroccan Atlantic offshore area (Figure 9) with the largest values observed from February to August interspersed by declined sharply potential during two months mainly April and May. WPD intensity decreases rapidly in September and October.

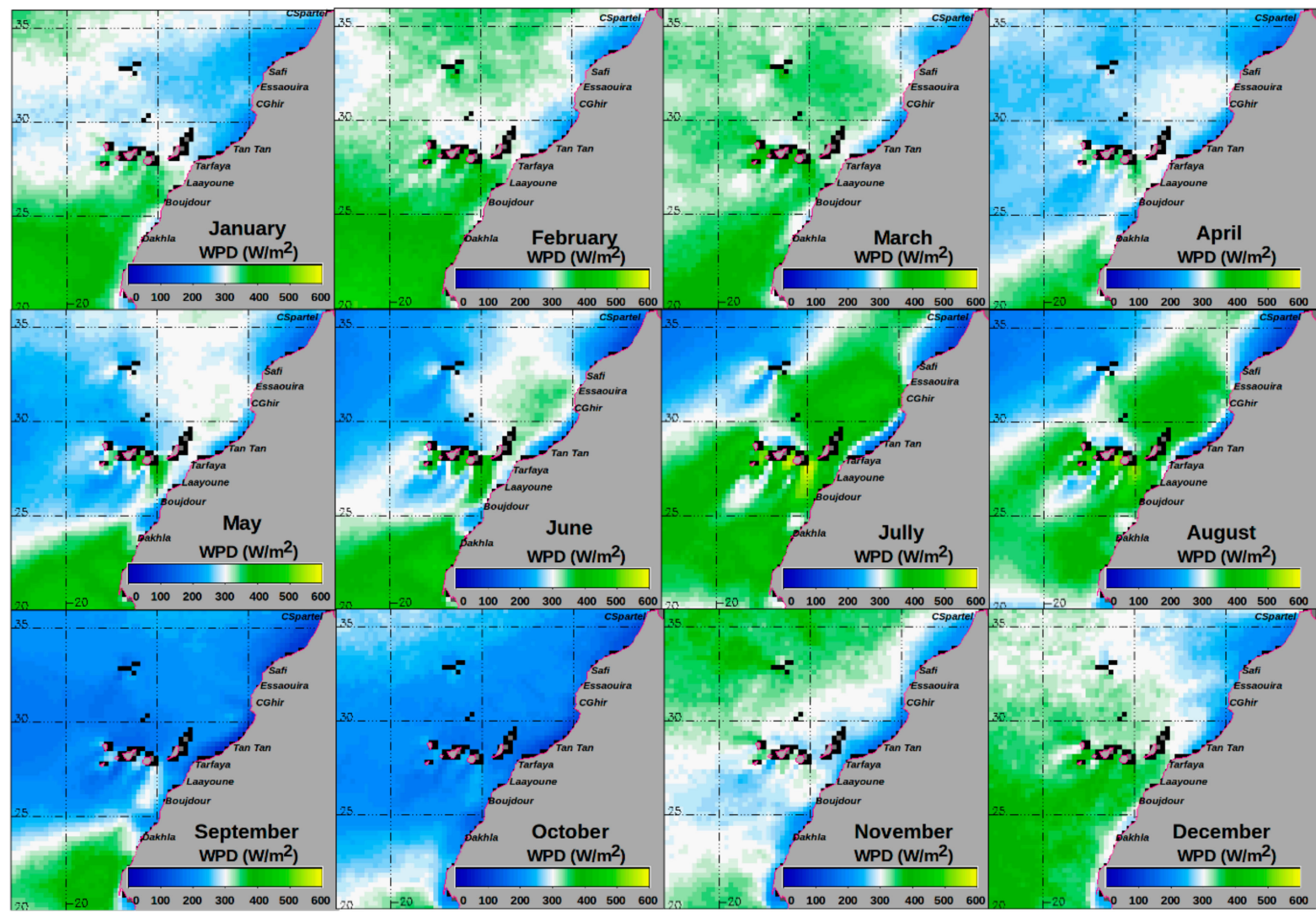

Figure 9. Monthly climatology of wind power density (WPD, W/m²) for the period 2008-2017 at $80 \mathrm{~m}$ a.s.l.

The maximum monthly power densities were identified in July at Dakhla, Essaouira and Laayoune, respectively, with power more than $577 \mathrm{~W} / \mathrm{m}^{2}, 445.46 \mathrm{~W} / \mathrm{m}^{2}$ and $441.48 \mathrm{~W} / \mathrm{m}^{2}$. On the other hand, the lowest power densities were recorded at Cap Ghir and Tan Tan with an annual mean power density less than $200 \mathrm{~W} / \mathrm{m}^{2}$. Although, the annual average is more than $200 \mathrm{~W} / \mathrm{m}^{2}$ for all the other sites.

The annual mean power densities (Figure 10) ranged between 150 and $250 \mathrm{~W} / \mathrm{m}^{2}$ in the northern part of the region (Cap Spartel, Safi, Essaouira and Cap Ghir) because of weaker winds and an unfavorable orientation of the coast line. In the central part (Tan Tan, Tarfaya and Boujdour) it was about $300 \mathrm{~W} / \mathrm{m}^{2}$. Further south, it is clear that Dakhla has the highest wind power density compared with the other sites about $577 \mathrm{~W} / \mathrm{m}^{2}$, with only two relatives minimums marked in March and during autumnal months, due to residual influence of the seasonal minimum of the trade winds in winter in the northern part of the system and in summer in its southern part. 


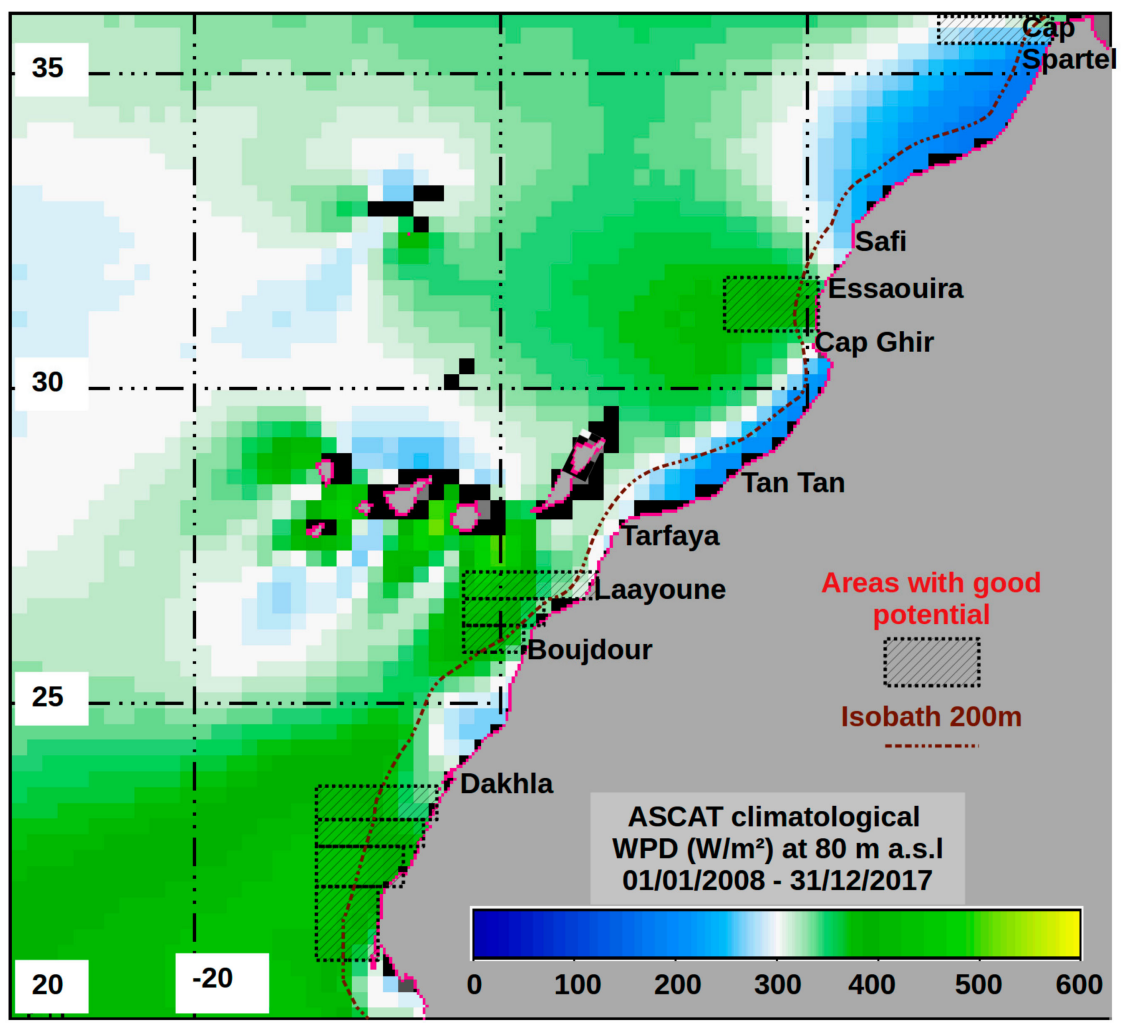

Figure 10. Annual average of WPD $\left(\mathrm{W} / \mathrm{m}^{2}\right)$ computed from 3653 daily images for the period 2008-2017; the likely potential areas of future offshore farms are highlighted according to the WPD intensity.

For more precision and to give a complementary snapshot on what is happening on the Moroccan continental shelf, the seasonal variability of the power density is described by the mean wind power densities via the Hovmoller space-time diagram at a $25 \mathrm{~km} / 1$-day spatio-temporal resolution, from $20^{\circ} \mathrm{N}$ to $36^{\circ} \mathrm{N}$ (Figure 11). The original data are smoothed with an 11-term moving average in time (11 days) and a 3-term moving average in space $(75 \mathrm{~km})$. The result shows a high spatio-temporal definition of the power density pattern, with well defined seasonal transitions from north to south.

Regarding the power density parameter presented in Figure 12, more important energetic peaks are noticed at Dakhla and Essaouira $\left(>450 \mathrm{~W} / \mathrm{m}^{2}\right)$ followed by Boujdour, Laayoune and Tarfaya with values in the range of $300-350 \mathrm{~W} / \mathrm{m}^{2}$. For the northern site mainly at Cap Spartel, the values do not exceed $200 \mathrm{~W} / \mathrm{m}^{2}$. Overall, this seasonality is similar to that found in other studies conducted by Allouhi [9], Elkhchine [19] and Daoudi [37] mainly focused at the Dakhla and Laayoune sites. Despite the discrepancies in terms of the maximum, this was defined in [19] as equal to $565.26 \mathrm{~W} / \mathrm{m}^{2}$.

As can be seen, the one exception to this pattern is in the Southern area, where WPD prevailed throughout the year as a consequence of the persistent wind. The northern area exhibited pronounced seasonal change, with WPD reaching values slightly below $\sim 250 \mathrm{~W} / \mathrm{m}^{2}$ in summer, declining to $200 \mathrm{~W} / \mathrm{m}^{2}$ through autumn, winter and spring.

Based on the power density classification approach adopted by the National Renewable Energy Laboratory (NREL) to consider whether a site has favorable power potential or not [38], we can conclude that southern Dakhla, Laayoune and Essaouira, with average annual wind power densities of more than $300 \mathrm{~W} / \mathrm{m}^{2}$ are economically viable for the grid-connected wind power systems. However, Cap Ghir and Tan Tan with annual power density average values that approach $200 \mathrm{~W} / \mathrm{m}^{2}\left(172 \mathrm{~W} / \mathrm{m}^{2}\right.$ and $154 \mathrm{~W} / \mathrm{m}^{2}$, respectively) were only suitable for the stand-alone wind power application. 

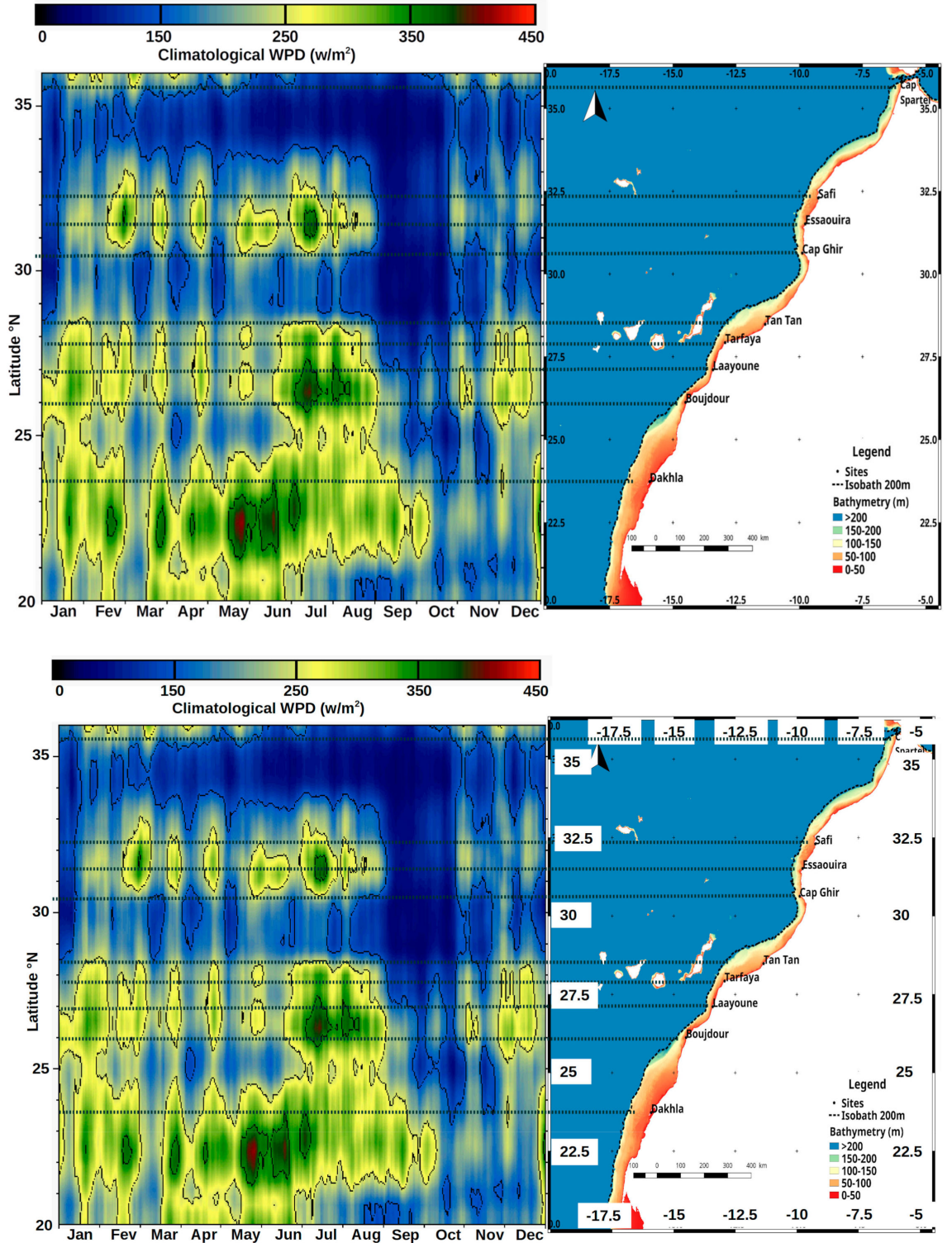

Figure 11. Seasonal mean of the power wind energy density.

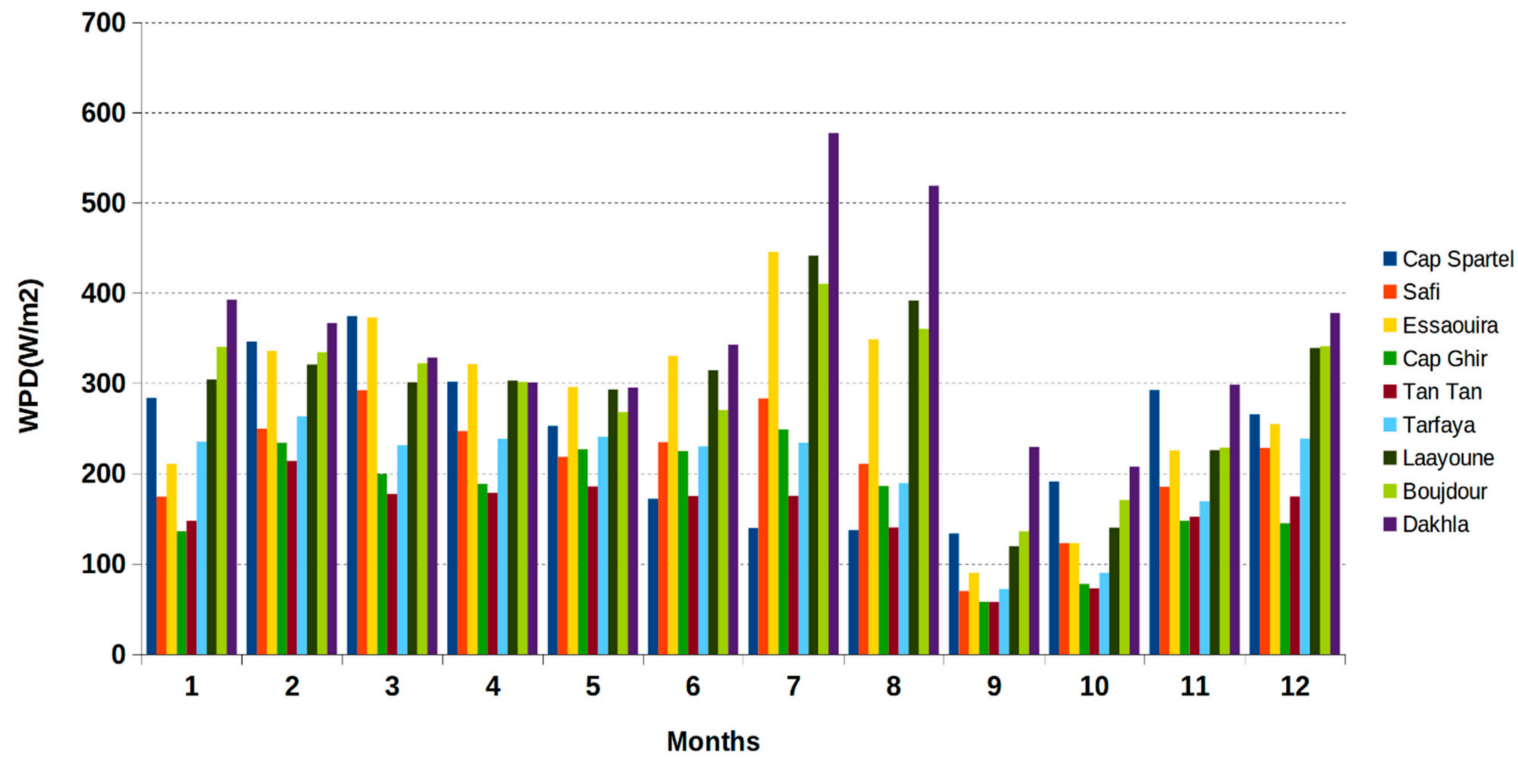

Figure 12. Climatological monthly variation of the WPD along each selected sites. 


\subsection{Considerations about Wind Technology and Bathymetry}

Offshore wind power is maturing, and the implementation of projects needs a comprehension of the wind potential and geological challenges posed by a given physical location. After ensuring the wind potential in the study area, we will focus on two parameters that are relevant factors that may affect and need to be considered when investigating the prospect of an offshore wind project: bathymetry and the distance from the shoreline [39].

Indeed, understand the variations in the geology of the sea is a huge determinant of the type of turbines that can operate above. A detailed assessment of ground conditions is given bellow showing that shallow water depth is highly variable from North to South (Figure 13).

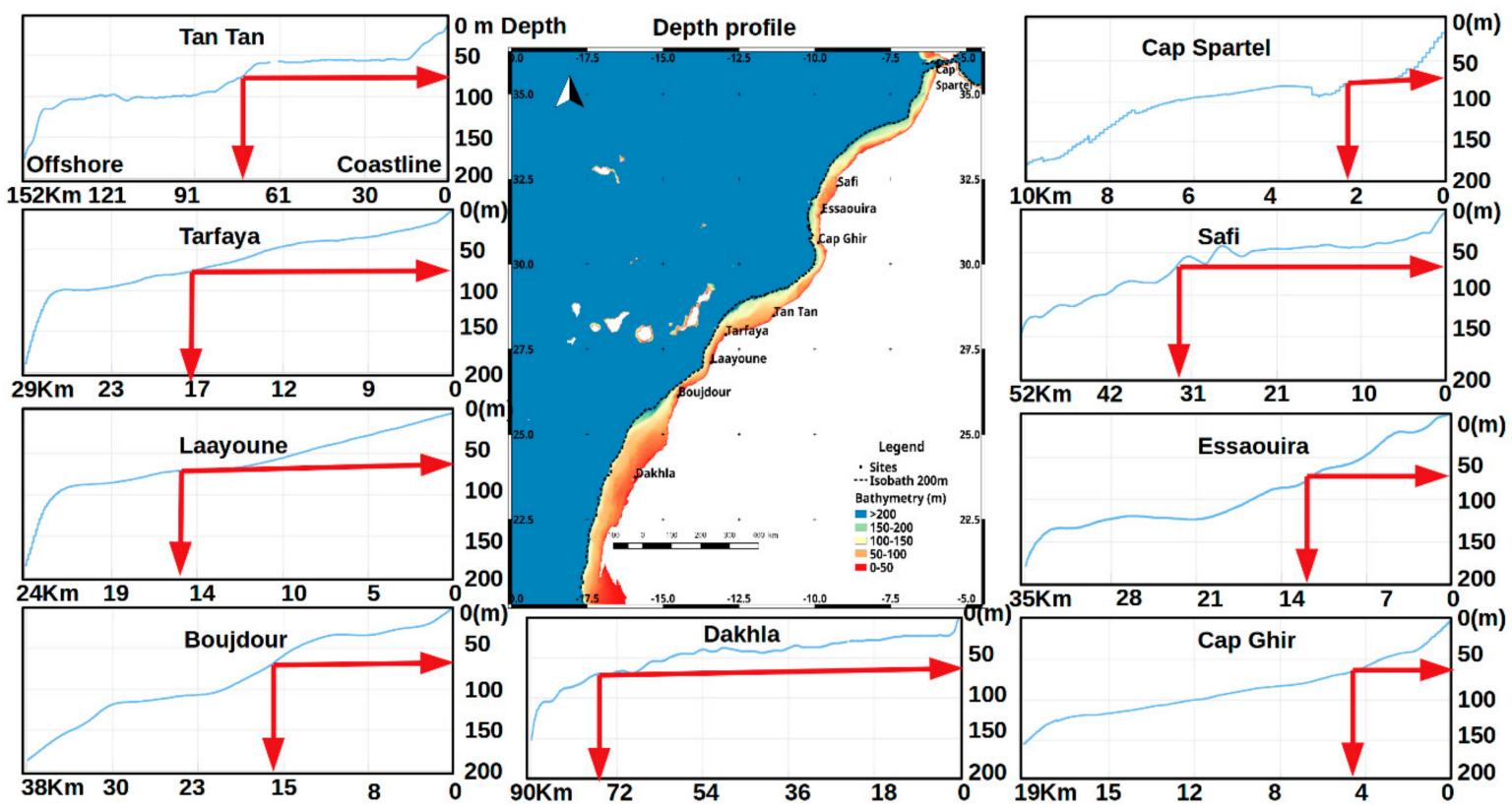

Figure 13. Depth profiles of the different sites from the shoreline to the offshore $200 \mathrm{~m}$ isobath limit. The red arrows point at the shallowest waters and the distance at which they are found. The depth delimitation at $60 \mathrm{~m} \mathrm{[37,38]} \mathrm{was}$ used to distinguish the possible floating technology resource from the likely reasonable upper economic limit of fixedbottom resource.

For physical characteristics of the study area, It was observed that shallow water extends the continental shelf from about $15 \mathrm{~km}$ at Cap Spartel to $75 \mathrm{~km}$ at Dakhla. The average width of the continental shelf is some $40 \mathrm{~km}$ to $50 \mathrm{~km}$ [40]. The head of the continental slope is situated at a depth of $200 \mathrm{~m}$ making the Moroccan Atlantic coast a potential area for housing all devices of wind energy.

Otherwise, knowing that the more offshore the farms, the greater the energy potential recovered, we have an interest in pushing into the deep limit offshore and adapting our technology to take advantage of powerful offshore wind fields.

Most offshore wind farms are located at distances typically $8 \mathrm{~km}$ ( $>3$ nautical miles) to $30 \mathrm{~km}$ ( 12 nautical miles) from the shoreline and placed in between 8 to $30 \mathrm{~m}$. Mainly, the offshore wind turbines are in general classified as: (i) shallow water foundation ( $5 \mathrm{~m}-30 \mathrm{~m})$ water depth, (ii) transitional water foundation $(30 \mathrm{~m}-60 \mathrm{~m})$, and (iii) deep water foundation (more than $60 \mathrm{~m}$ depth) [41].

Both these shallow water and transitional offshore wind turbines have fixed foundations whereas the deep water offshore wind turbines are generally floating structures.

Based on that, we can propose a synthetic classification scheme for the different technologies to be deployed for each site according to topographic features of the continental shelf and to the seaward distance at which the shallow water is located (Table 3). 
Table 3. Synthetic table of the likely technologies to be deployed for each site off Morocco according to the topographic features of the continental shelf.

\begin{tabular}{|c|c|c|c|c|c|c|c|}
\hline \multirow{2}{*}{ Sites } & \multicolumn{2}{|c|}{ Speed at $80 \mathrm{~m}$} & \multicolumn{2}{|c|}{ WPD at $80 \mathrm{~m}$} & \multirow[t]{2}{*}{$\begin{array}{l}\text { Width of the } \\
\text { Continental Shelf }\end{array}$} & \multirow[t]{2}{*}{$\begin{array}{l}\text { Distance of the } \\
\text { Shallow Water }\end{array}$} & \multirow[t]{2}{*}{ Foundation } \\
\hline & Max & Mean & Max & Mean & & & \\
\hline Cap Spartel & 8.48 & 7.23 & 374.10 & 240.67 & very narrow & $<3 \mathrm{NM}$ & Floating \\
\hline Safi & 7.81 & 6.91 & 292.2 & 209.54 & Medium & $\sim 12 \mathrm{NM}$ & Fixed \\
\hline Essaouira & 8.99 & 7.56 & 445.46 & 279.44 & Medium & $\sim 12 \mathrm{NM}$ & Fixed \\
\hline Cap Ghir & 7.40 & 6.45 & 248.71 & 172.63 & very narrow & $<3 \mathrm{NM}$ & Floating \\
\hline Tan Tan & 7.039 & 6.24 & 213.66 & 154.04 & Wide & $>24 \mathrm{NM}$ & Fixed \\
\hline Tarfaya & 7.547 & 6.82 & 263.24 & 202.55 & Medium & $\sim 12 \mathrm{NM}$ & Fixed \\
\hline Laayoune & 8.97 & 7.71 & 441.48 & 291.04 & Medium & $>3 \mathrm{MN}<12 \mathrm{MN}$ & Floating \\
\hline Boujdour & 8.75 & 7.72 & 410.15 & 290.10 & Medium & $>3 \mathrm{MN}<12 \mathrm{MN}$ & Floating \\
\hline Dakhla & 9.8 & 8.25 & 577.26 & 352.95 & Wide & $>24 \mathrm{NM}$ & Fixed \\
\hline
\end{tabular}

This leads us to classify the region of Morocco into three groups

- Group 1: Very narrow continental shelf

This group includes sites having a very narrow continental shelf, mainly Cap Spartel and Cap Ghir, where the seaward distance from the shoreline of the shallower waters is very short $(<3 \mathrm{NM})$.

\section{- $\quad$ Group 2: Thin continental shelf}

The shelf break of the sites of this group (Northern Essaouira and Safi, Laayoune and Boujdour) is up to 12 nautical miles, and the distance offshore of the shallower water is closer to the shoreline. This region can be considered as transitional region between the closer coast area and offshore area.

- Group 3: Very wide continental shelf

The continental shelf of this group mostly in the area including Tan Tan and Dakhla is very wide with a very gentle slope and the shallower waters are extended beyond 24 nautical mile up to a distance of $75 \mathrm{~km}$ offshore. These sites present a good energetic potential with mean wind speed $>8 \mathrm{~m} \mathrm{~s}^{-1}$ and WPED $>300 \mathrm{~W} / \mathrm{m}^{2}$ at $80 \mathrm{~m}$ a.s.l.

Fixed foundation offshore turbines could potentially deployed in up to $60 \mathrm{~m}$ of water for the sites of groups 2 and 3 . However, for the sites of group 1, floating support structures offer the possibility for deployment in much deeper waters in the sites of this group.

\section{Conclusions}

The objective of the study presented is mainly concerned with the evaluation of the available wind energy potential along the Moroccan continental shelf with a focus on particular sites over one decade from 2008 to 2017. The use of ASCAT data has led to a very fine synoptic analysis of energy resources both spatially and temporally where in situ measurements are missing. Based on these data, we presented a spatial continuity evaluation of offshore wind resources with a spatial resolution of 0.25 degrees and daily time step.

The choice of the climatological cycle has proven to be useful to map and analyze the variations over the monthly and seasonal time scale of the wind speed and for investigating the wind potential density.

A detailed statistical study of wind at $10 \mathrm{~m}$ and $80 \mathrm{~m}$ a.s.l along the Kingdom of Morocco shoreline is presented. The most important outcomes of the study can be summarized as follows:

1. Wind characteristic analysis for nine sites of Moroccan shoreline was conducted and the seasonal maps and wind roses are presented.

2. The wind roses and Hovmoller analysis showed the prevailing wind directions for $10 \mathrm{~m}$ height over sea level. 
3. Wind distribution was modeled using the Weibull probability function and the Weibull parameters were calculated. The results show the lowest variability of wind mainly on the South.

4. ASCAT data can be used to usefully map wind resources in countries with large extensional areas.

5. The offshore winds that blow over the Atlantic shelves are a strong asset for the country. Wind resources are suitable for economically attractive electric generation, with three regions of higher productivity, the northern area at Cap Spartel, central area near Essaouira and the southern area in front and south of Dakhla.

6. Regarding the power density parameter, the wind potential is on average $200 \mathrm{~W} / \mathrm{m}^{2}$ for the entire region. This value varies depending on the season and month. The maximum energy density at height of $80 \mathrm{~m}$ a.s.l is more than $500 \mathrm{~W} / \mathrm{m}^{2}$ at the Dakhla site followed by Boujdour, Laayoune, Tarfaya and Essaouira with values in the range of $350-450 \mathrm{~W} / \mathrm{m}^{2}$. For the northern stations, the average values do not exceed $200 \mathrm{~W} / \mathrm{m}^{2}$. On the other hand, a production peak is observed at the Essaouira site during the summer, although the average annual production does not exceed $300 \mathrm{~W} / \mathrm{m}^{2}$.

7. The large energy resource in the southern area is attributed to a large wind intensity. These southern areas tend to have a high quantity of resources at wind speeds between $7 \mathrm{~m} \mathrm{~s}^{-1}$ and $8 \mathrm{~m} \mathrm{~s}^{-1}$ and wide continental shelves.

8. These regions can potentially benefit from their proximity to harbor structures and planned projects which make them promising regions for possible exploitation of wind energy.

The processed data set provides informative potential with precise spatial and temporal remotely sensed information. Comparative studies should be conducted in order to improve and complete the assessment of the wind energy potential. A combination of different Scatterometer data, and the use of in situ measurements derived from offshore buoys, are highly desirable.

Author Contributions: A.B. conceived the original idea of the study, designed, organized and wrote the article; H.M., contributed in design and organization, analyze and discuss the results and wrote the article. K.E.H. and B.Z. assisted in manuscript preparation and revision; S.M. supervised the entire investigation. All authors have read and agreed to the published version of the manuscript.

Funding: This research received no external funding.

Institutional Review Board Statement: Not applicable.

Informed Consent Statement: Not applicable.

Data Availability Statement: The data presented in this study are available on request from the corresponding author.

Conflicts of Interest: The authors declare no conflict of interest.

\section{References}

1. Kumar, Y.; Ringenberg, J.; Depuru, S.S.; Devabhaktuni, V.K.; Lee, J.; Nikolaidis, E.; Andersen, B.; Afjeh, A. Wind energy: Trends and enabling technologies. Renew. Sust. Energy Rev. 2106, 53, 209-224. [CrossRef]

2. Huang, J.; Mc Elroy, M.B. A 32-year perspective on the origin of wind energy in warming climate. Renew. Energy 2015, 77, 482-492. [CrossRef]

3. Intergovernmental Panel on Climate Change. Climate Change. Impacts, Adaptation and Vulnerability. In Contribution of Working Group II to the Fourth Assessment Report of the Intergovernmental Panel on Climate Change; Parry, M.L., Canziani, O.F., Palutikof, J.P., van der Linden, P.J., Hanson, C.E., Eds.; Cambridge University Press: Cambridge, UK, 2007.

4. Sellers, B.J.; Voltaire, J.A.; Gustafson, S.M.; Hartman, W.A. Energy Sustainability in Morocco. 2015. Available online: https: //digitalcommons.wpi.edu/iqp-all/787 (accessed on 28 December 2020).

5. Second Edition of Ministry Media day under Theme “Energy and Mining, Levers for Sustainable Development: Assessments and Prospects", Second the Ministry of Energy, Mining, and Sustainable Development Organized on Wednesday. 9 January 2019. Available online: www.mem.gov.ma (accessed on 28 December 2020). 
6. Masen (Moroccan Agency for Sustainable Energy) The Integrated Wind Project 850 MW, Infographics. 2017. Available online: www.masen.ma (accessed on 28 December 2020).

7. Haddouche. Renewable Energy Policy and Wind Energy in Morocco; CDER Center for Renewable Energies Development: Marrakech, Morocco, 2006.

8. European Marine Observation and Data Network Bathymetry. Available online: https://www.emodnet-bathymetry.eu/dataproducts (accessed on 28 December 2020).

9. Allouhi, A.; Kousksou, T.; Jamil, A.; El Rhafiki, T.; Mourad, Y.; Zeraouli, Y. Economic and environmental assessment of solar air-conditioning systems in Morocco. Renew. Sustain. Energy Rev. 2015, 50, 770v81. [CrossRef]

10. El Mghouchi, Y.; Ajzoul, T.; El Bouardi, A. Prediction of daily solar radiation intensity by day of the year in twenty-four cities of Morocco. Renew. Sustain. Energy Rev. 2016, 53, 823-831. [CrossRef]

11. ONEE: Chiffres Clés 2019. Available online: http://www.one.org.ma/FR/pdf/Depliant\%20Statistiques\%20FR\%202019.pdf (accessed on 28 December 2020).

12. Renewable Energy Solutions for the Mediterranean \& Africa, Country Profile Morocco. 2018. Available online: https://www.res4 med.org/wp-content/uploads/2018/06/Country-profile-Marocco-2.pdf (accessed on 28 December 2020).

13. GWEC (Global Wind Energy Council). Global Wind Report; GWEC: Brussels, Belgium, 2019.

14. IEA (International Energy Agency). Offshore Wind Outlook; IEA: Paris, France, 2019.

15. Kousksou, T.; Allouhi, A.; Belattar, M.; Jamil, A.; El Rhafiki, T.; Arid, A.; Zeraouli, Y. Renewable energy potential and national policy directions for sustainable development in Morocco. Renew. Sustain. Energy Rev. 2015, 47, 46-57. [CrossRef]

16. World Wide Fund. Environmental Impacts of Offshore Wind Power Production in the North Sea: A Literature Overview; World Wide Fund for Nature (WWF): Oslo, Norway, 2014.

17. Enzili, M.; Nayysa, A.; Affani, F.; Simonis, P. Wind energy in Morocco, potential—State of the art-Perspectives. DEWI Mag. 1998, 12, 42-44.

18. El Khchine, Y.; Sriti, M.; El Kadri, N.D. Evaluation of wind energy potential and trends in Morocco. Heliyon 2019, 5, e01830. [CrossRef]

19. Hasager, C.B. Offshore winds mapped from satellite remote sensing. WIREs Energy Environ. 2014, 3, 594-603. [CrossRef]

20. Guo, Q.; Xu, X.; Zhang, K.; Li, Z.; Huang, W.; Mansaray, L.R.; Liu, W.; Wang, X.; Gao, J.; Huang, J. Assessing Global Ocean Wind Energy Resources Using Multiple Satellite Data. Remote Sens. 2018, 10, 100. [CrossRef]

21. Bagiorgas, H.S.; Mihalakakou, G.; Rehman, S.; Al-Hadhrami, L.M. Wind Power Potential Assessment for Seven Buoys Data Collection Stations in Aegean Sea Using Weibull Distribution Function. J. Renew. Sustain. Energy 2012, 4, 1-16. [CrossRef]

22. Talha Arslan, N.; Murat Bulut, Y.; Arzu Altın, Y. Comparative study of numerical methods for determining Weibull parameters for wind energy potential. Renew. Sustain. Rev. 2014, 40, 820-825. [CrossRef]

23. Pavia, E.G.; O'Brien, J.J. Weibull statistics of wind speed over the ocean. J. Clim. Appl. Meteorol. 1986, 25, 1324-1332. [CrossRef]

24. Savenkov, M. On the Truncated Weibull Distribution and its Usefulness in Evaluating the Theoretical Capacity Factor of Potential Wind (or Wave) Energy Sites. J. Eng. Technol. 2009, 1, 21-25.

25. Troen, I.; Petersen, E.L. European Wind Atlas; Risoe National Laboratory: Roskilde, Danemark, 1989.

26. Weibull, W. A Statistical Distribution Function of Wide Applicability. J. Appl. Mech. 1951, 103, $293-297$.

27. Fazelpour, F.; Soltani, N.; Soltani, S.; Rosen, M.A. Assessment of wind energy potential and economics in the north-western Iranian cities of Tabriz and Ardabil, Renew. Sustain. Energy Rev. 2015, 45, 87-99. [CrossRef]

28. Liu, W.T.; Tang, W.; Xie, X. Wind power distribution over the ocean. Geophys. Res. Lett. 2008, 35. [CrossRef]

29. Harvesting the Wind: The Physics of Wind Turbines. Carleton College. 2005. Available online: http://digitalcommons.carleton. edu/pacp/7 (accessed on 28 December 2020).

30. Carvalho, D.; Rocha, A.; Gomez-Gesteira, M.; Silva Santos, C. Offshore winds and wind energy production estimates derived from ASCAT, OSCAT, numerical weather prediction models and buoys-A comparative study for the Iberian Peninsula Atlantic coast. Renew. Energy 2017, 102, 433-444. [CrossRef]

31. Soukissian, T.; Karathanasi, F.; Axaopoulos, P. Satellite-based offshore wind resource assessment in the Mediterranean Sea. IEEE J. Ocean Eng. 2017, 42, 73-86. [CrossRef]

32. Nagababu, G.; Kachhwaha, S.S.; Savsani, V. Estimation of technical and economic potential of offshore wind along the coast of India. Energy 2017, 138, 79-91. [CrossRef]

33. Benazzouz, A.; Mordane, S.; Orbi, A.; Chagdali, M.; Hilmi, K.; Atillah, A.; Pelegrí, J.L.; Demarcq, H. An improved coastal upwelling index from sea surface temperature using satellite-based approach-The case of the Canary Current upwelling system. Cont. Shelf Res. 2014, 81, 38-54. [CrossRef]

34. Pimenta, F.; Kempton, W.; Garvine, R. Combining meteorological stations and satellite data to evaluate the offshore wind power resource of southeastern Brazil. Renew. Energy 2008, 33, 2375-2387.

35. Salvação, N.; Soares, C.G. Offshore wind energy assessment for the Iberian coasts using remotely sensed data. In Renewable Energies Offshore; Soares, C.G., Ed.; Taylor \& Francis Group: Didecott, UK, 2015; pp. 237-244.

36. Balog, I.; Ruti, P.M.; Tobin, I.; Armenio, V.; Vautard, R. A numerical approach for planning offshore wind farms from regional to local scales over the Mediterranean. Renew. Energy 2016, 85, 395-405.

37. Daoudi, M.; Abdelaziz, A.S.M.; Mohammed, E.; Elmostapha, E. Wind speed data and wind energy potential using Weibull distribution in Zagora, Morocco. Int. J. Renew. Energy Dev. 2019, 8, 267-273. [CrossRef] 
38. Heimiller, D.; Beiter, P.; Scott, G.; Draxl, C. Offshore Wind Energy Resource Assessment for the United States Walt Musial. National Renewable Energy Laboratory. 2016. Available online: www.nrel.gov/publications (accessed on 28 December 2020).

39. Moller, B.; Hong, L.; Lonsing, R.; Hvelplund, F. Evaluation of offshore wind resources by scale development. Energy 2012, 48, 314-322. [CrossRef]

40. Mhammdi, N.; Snoussi, M.; Medina, F.; Jaaïdi, E.B. Chapter 10 Recent sedimentation in the NW African shelf. Geol. Soc. London Mem. 2014, v.41, 131-146. [CrossRef]

41. Elsner, P.; Suarez, S. Renewable energy from the highseas: Geo-spatial modelling of resource potential and legal implications ford eveloping offshore wind projects beyond the national jurisdiction of coastal states. Energy Policy 2019, 128, 919-929. [CrossRef] 